\title{
ВНУТРІШНІ ХВОРОБИ
}

\section{ДВНЗ “Тернопільський державний медичний університет імені І. Я. Горбачевського” КЛІНІЧНИЙ ПОЛІМОРФІЗМ ТА ДИФЕРЕНЦІЙНА ДІАГНОСТИКА ХВОРОБИ ЛАЙМА}

\begin{abstract}
Резюме. Лайм-бореліоз - це хронічне природно-осередкове трансмісивне інфекційне зоонозне захворювання, що спричиняють борелії Borrelia burgdorferi sensu lato (Bbsl). Західний регіон України, у тому числі Тернопільська область, є ендемічним осередком хвороби Лайма. У статті представлено огляд літератури, присвячений аналізу поліморфізму клінічних проявів лайм-бореліозу, наведено дані щодо диоеренційної діагностики лайм-дерматиту, лайм-артриту та нейробореліозу.

Мета дослідження - вивчити захворення на лайм-бореліоз для поліпшення діагностики та просрілактики його серед населення України.

Матеріали і методи. Проведено анкетування 326 людей віком від 5 до 80 років. За допомогою статистичного методу визначено річну сезонність та місця укусів опитаних людей кліщами, кількість осіб, яким проводили лабораторні дослідження крові на предмет виявлення борелій та профрілактичне лікування, проаналізовано скарги хворих.

Результати досліджень та їх обговорення. В Україні циркулюють 5 штамів борелій комплексу Bbsl: Bbss, B.afzelii, B.garinii, B.valasiana, A14S. Дані геновиди борелій асоціюються з переважанням відповідних клінічних фрорм лайм-бореліозу: артрити - 3 Bbss, неврологічна манісестація - з B. garinii, шкірні прояви - з B. afzelii. Bbs/ є причиною етіологічно недіагностованих $(16,7 \%)$ неврологічних та $(20,7$ \%) псевдоревматологічних патологій. Серед 326 осіб віком від 5 до 80 років, яких ми анкетували, було 229 з укусами кліщів. Характерна річна сезонність захворювання пов'язана з періодами активності кліщів. 59,2 \% укусів кліщами серед опитаних осіб були влітку, 25,7 \% - навесні, 15,1 \% - восени. Лабораторні дослідження крові серед укушених на предмет виявлення борелій проводили 20 (8,73 \%) пацієнтам, у 6 був позитивний результат. Найчастіше хворі скаржилися на появу мігруючої еритеми (10 осіб) та появу суглобових набряків (6 осіб).

Висновки. Хвороба Лайма - це хронічне інфекційне трансмісивне зоонозне природно-осередкове захворювання, яке характеризується циклічним перебігом і мультисистемністю уражень. В Україні циркулюють 5 штамів борелій комплексу Bbsl. Дифреренційну діагностику захворювань на лайм-бореліоз проводили з бешихою, токсикодермією, еризипелоїдом, укусами членистоногих, ревматизмом, ревматоїдним артритом, іноекційними та інвазійними менінгітами, кліщовим енцесралітом, порушенням мозкового кровообігу різної природи, розсіяним склерозом, синдромом Гієна-Барре.
\end{abstract}

Ключові слова: хвороба Лайма; лайм-бореліоз; Borrelia burgdorferi sensu lato; мігруюча еритема; міокардит; ураження нервової системи.

ВСТУП В Україні показники захворюваності на хворобу Лайма (ХЛ) з 2000 р. до 2010 р. збільшились у 29 разів [1]. У 2015 р. захворюваність на кліщовий бактеріоз досягла 7,96 на 100 тис. населення. Абсолютне число хворих на ХЛ у 2016 р. становило 2758 [2]. Західний регіон України, у тому числі Тернопільська область, $є$ ендемічним осередком ХЛ. Міський відділ та лабораторія особливо небезпечних інфекцій дУ "Тернопільський обласний лабораторний центр Держсанепідслужби України" за 2016 р. на основі клінікоепідеміологічних даних виявили і підтвердили лабораторно 903 випадки захворюваності на лайм-бореліоз [3].

ХЛ (лайм-бореліоз, лаймська хвороба, іксодовий кліщовий бореліоз, системний кліщовий бореліоз; morbus Lyme, МКБ-10:A69.2) - це хронічне природно-осередкове трансмісивне інфекційне зоонозне захворювання, яке спричиняють борелії Borrelia burgdorferi sensu lato (Bbsl). За структурою ДНК розрізняють 16 геномних штамів борелій комплексу Bbsl. Переносниками ХЛ є іксодові кліщі [4]. Резервуарами борелій є понад 130 видів ссавців та близько 100 видів птахів [5]. Виділяють два піки ХЛ: весняно-літній період (квітень-червень), кінець літа-початок осені (серпень-жовтень) [6].

Метою дослідження було вивчення лайм-бореліозу за результатами анкетування та проведеним оглядом літератури для поліпшення діагностики та просрілактики даного захворювання серед населення України.

МАТЕРІАЛИ I МЕТОДИ Проведено анкетування 326 людей віком від 5 до 80 років. За статистичним методом визначено річну сезонність та місця укусів опитаних людей кліщами, кількість осіб, яким проводили лабораторні дослідження крові на предмет виявлення борелій та профрілактичне лікування, проаналізовано скарги хворих.

РЕЗУЛЬТАТИ ДОСЛІДЖЕНЬ ТА ЇХ ОБГОВОРЕННЯ Серед 326 анкетованих людей було 229 осіб, яких укусили кліщі, 3 них 133 - жіночої статі, 96 - чоловічої статі. Характерна річна сезонність укусів, яка пов'язана з періодами активності кліщів. Навесні в опитаних людей було 124 (25,7 \%) укуси кліщами, влітку - 286 (59,2 \%), восени - 73 (15,1 \%), взимку - жодного випадку (рис. 1).

На рисунку 2 видно, що найчастіше укуси були у ділянці тулуба (101 випадок), найрідше - у ділянці голови (20 випадків). Лабораторні дослідження крові серед укушених на предмет виявлення борелій проводили 20 $(8,73 \%)$ пацієнтам, у 6 був позитивний результат. 8 осіб отримували профрілактичне лікування доксацикліном та іншими антибіотиками з приводу бореліозу.

Ми проаналізували скарги хворих, яких укусили кліщі (рис. 3). Найчастіше люди скаржилися на появу мігруючої еритеми (10 осіб) та суглобових набряків (6 осіб).

Згідно з наказом МОЗ України № 778 від 28.10.2014 p., ХЛ віднесено до орфанних (рідкісних) інфекцій [2]. Через
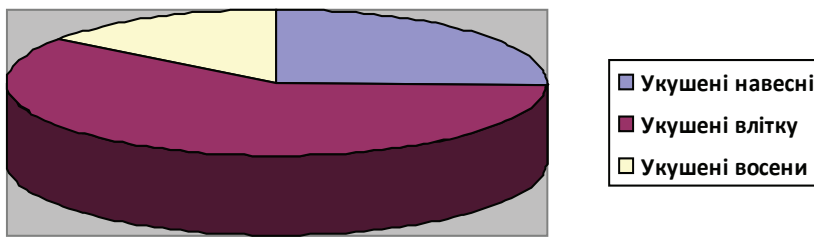

Рис. 1. Сезонність укусів кліщами опитаних людей. 


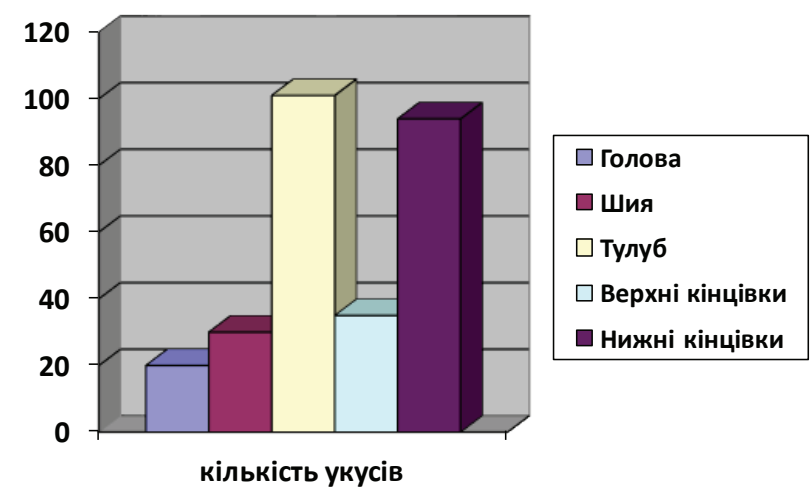

Рис. 2. Місця укусів кліщами опитаних людей.

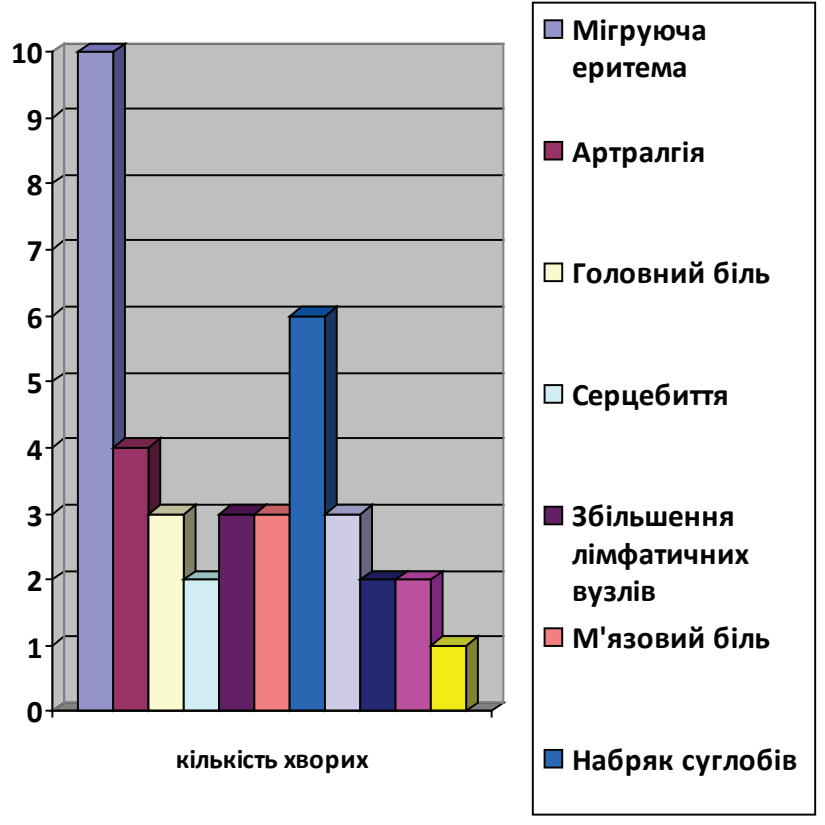

Рис. 3. Клінічні прояви укусів кліщів.

поліморфізм клінічних симптомів ХЛ ще називають "великий імітатор" [7]. Bbs/ є причиною етіологічно недіагностованих 16,7 \% неврологічних та 20,7 \% псевдоревматологічних патологій [8]. В Україні циркулюють 5 штамів борелій комплексу Bbsl: Bbss, B .afzelii, B. garinii, B. valasiana, A14S [9]. Дані геновиди борелій асоціюються 3 переважанням відповідних клінічних фрорм ХЛ: артрити - з Bbss, неврологічна маніфрестація - 3 B. garinii, шкірні прояви - 3 B. afzelii [8].

Інкубаційний період при ХЛ складає 3-32 дні. Розрізняють три клінічні стадії захворювання: 1) рання локалізована, що триває декілька тижнів; для неї характерні мігруючі шкірні прояви, можливі різноманітні алгії (головний, суглобовий, м'язовий біль) без порушення функції органів; 2) рання дисемінована (триває декілька тижнів); у цей період на тлі вторинної еритеми виявляють клінічні ознаки уражень різноманітних органів (серце, нервова система, дещо менше - суглоби, очі тощо); 3) пізня хронічна (розвивається через декілька місяців, триває декілька років); характеризується змінами в нервовій системі, що прогресують, виникненням стійких ушкоджень суглобів, іноді їх деструкцією [7].
У 70 \% випадків через 6-12 год у місці укусу з'являються свербіж і відчуття дискомфорту. Після відпадання кліща формується первинний афект у вигляді еритемної макули або папули розміром 3-5 мм із кірочкою в центрі, що зберігається впродовж 2-3 тижнів. За рекомендаціями ВОО3, первинний афект розміром 2-5 см на тлі негативних у динаміці результатів специсрічної діагностики ХЛ розцінюється як алергічна реакція на укус кліща [8]. При ХЛ навколо первинного афекту розвивається гіперемія шкіри діаметром 3-70 см (мігруюча еритема або еритема Афцеліуса-Ліпшютца). Зовнішня межа еритеми не підвищується над рівнем шкіри, забарвлена інтенсивніше, ніж центральна частина (кільцеподібна мігруюча еритема). Еритемі властивий периферичний ріст [10]. При адекватній етіотропній терапії до 10 дня еритема, як правило, зменшується, залишаючи у $50 \%$ пацієнтів постінсрламаторну гіперпігментацію ("тінь еритеми"), яка з часом зникає. Еритема може бути єдиною ознакою гострого періоду ХЛ, але частіше її супроводжують регіонарна лімфраденопатія, симптоми загальноінфекційного синдрому (слабість, помірна лихоманка, головний біль, міалгії, артралгії) [6]. Типова мігруюча еритема понад 5 см в діаметрі $є$ підставою для встановлення діагнозу ХЛ навіть без лабораторного підтвердження (рекомендації ВООЗ 1995 р.) [8]. При хронічній стадії ХЛ дерматобореліоз проявляється доброякісною лімфоцитомою шкіри (вузликові елементи, пухлиноподібні утворення або нечітко обмежені інорільтрати в дермі, які розташовані на обличчі, в пахових ділянках, шкіра над ними від синюшночервоного до коричневого кольору, неболюча), акродерматитом (атрофрія дерми із місцевою гіперпігментацією, процес частіше локалізується на кінцівках, має одно- або двобічну локалізацію) $[6,7,10,11]$.

У разі шкірних проявів проводять диференційну діаностику ХЛ із бешихою, токсикодермією, еризипелоїдом, алергічною реакцією на укуси членистоногих. При еритематозній формі бешихи спочатку з'являється червона пляма, яка швидко поширюючись, змінюється на велику еритему яскраво-червоного забарвлення 3 нерівними (“язики полум'я", “географрічна мапа") і чіткими (валик по перифрерії) межами ділянки ураження. При розладах лімфообігу пляма має ціанотичний відтінок, при трофрічних порушеннях дерми із лімфо-венозною недостатністю бурий. Шкіра у зоні запалення інорільтрована, вилискує, напружена, гаряча на дотик, помірно болісна при пальпації, більше по периферії. Набряк поширюється за межі еритеми і більше виражений в місцях із розвинутою підшкірно-жировою клітковиною (повіки, губи, статеві органи тощо). Розміри еритеми збільшуються за рахунок периферійного росту. При розвитку еритематозно-бульозної чи еритематозно-геморагічної форм бешихи на тлі еритеми з'являються відповідно міхурі або геморагії, а при розвитку бульозно-геморагічного ураження міхурі містять геморагічний ексудат і фрібрин. Для того, щоб у людини виникла бешиха, потрібні умови: наявність $\beta$-гемолітичного стрептокока групи А, попередньої сенсибілізації певної ділянки шкіри до стрептокока, яка зумовлена наявністю вогнища інфекції (наприклад, ушкодження міжпальцевих ділянок на ногах сприяє виникнення бешихи гомілки; хронічний отит, гайморит підвищують ймовірність появи бешихи обличчя), чинника, що провокує розвиток захворювання (наприклад, операційне втручання на молочній залозі, кінцівках сприяє виникненню місцевих порушень гемодинаміки та лімфостазу) [7]. 
Для еризипелоїду Розенбаха або свинячої пики характерний контактний механізм зараження - через ушкоджену шкіру при роботі з інфрікованим м'ясом, випадковому уколі кістками тварин або риб, контакті з хворими тваринами (свинями, вівцями, ВРХ). Дане зоонозне інфекційне захворювання шкіри спричиняє паличка свинячої бешихи Erysipelothrix rhusiopathiae (українською "нитка червоної шкіри при червоній патології”), яка належить до родини Corynebacteriaceae. На пальцях кисті, зап'ястка видно добре відмежовану яскраво-червону бляшку з гладкою, блискучою поверхнею, яка тепла на дотик, не напружена $[12,13]$. Згодом колір бляшки змінюється на коричневий, зрідка можуть з'явитися міхурі (булли). Дифуузна шкірна форма еризипелоїду проявляється на різних частинах тіла множинними, добре розмежовані фріолетовими бляшками із чіткими межами та деяким побліднінням та западанням у центрі. Іноді з'являється місцеве печіння або невеликий біль.

Первинний афект при ХЛ потрібно диференціювати із укусами членистоногих. У Південних областях України (Херсонська, Миколаївська, Одеська), у степових районах Криму поширені отруйні павуки: каракурти (Latrodectus mactans tredecimguttatus Rossi) та тарантули (Lycosa singoriensis Lazm) [14]. У місці укусу павуків видно дві точки, оскільки отрута знаходиться в основі двох хеліцер членистоногого [15]. Під час укусу каракурта відчувається миттєвий пекучий біль, який через 15-30 хв поширюється по всьому тілу. Характерні прояви інтоксикації (озноб, головний біль, нудота, блювання, тахікардія), біль у животі, попереку, грудях, оніміння кінцівок, відчуття страху. Також можуть виникати напруження м'язів передньої черевної стінки, бронхоспазм, затримка сечовипускання та дефекації. Загальні клінічні прояви тривають декілька діб. У разі тяжкого ураження нервової системи можлива зупинка дихання. Отрута, що потрапляє у рану під час укусу тарантула, як правило, спричинює місцеві зміни (біль, набряк, гіперемію). На відміну від укусу каракурта, біль не іррадіює в інші ділянки тіла, прояви інтоксикації не виражені [14].

На півдні України зустрічається кримський скорпіон (Euscorpius tauricus), отрута якого має нейротропну та кардіотоксичну дії. Так, як отруйна залоза знаходиться в останньому членику черевця (тельсоні), який закінчується отруйною голкою, то на місці ужалення навколо видно одну точку. Через 30-40 хв 3'являється набряк, почервоніння розміром 5-10 см, біль поширюється за ходом нервів і змінюється онімінням. Загальні прояви з'являються через 5 хв -24 год. Характерні озноб, відчуття страху, головний біль, кардалгії, серцебиття, задуха, слинотеча, нудота, судоми. Можливий параліч дихання [16].

При ХЛ у 15-20 \% хворих має місце ураження серця [17]. Лайм-кардит спостерігається на ранній дисемінованій стадії захворювання (через 1-3 місяці з моменту інорікування) [7]. Кардіологічні прояви у пізні терміни (понад 6 місяців) вважають не спричиненами бореліозною інсрекцією. До клінічних симптомів ураження серця при ХЛ належать: кардалгії, серцебиття, задишка, головокружіння, короткочасні синкопальні стани. При цьому діагностують міокардит. У 20-25 \% випадків усіх кардіологічних проявів при ХЛ відмічають порушення серцевого ритму [6]. Найчастіше на ЕКГ реєструють атріовентрикулярну блокаду (AV-блокаду). У багатьох хворих виявляють "мінорні" ознаки міокардиту, без будь-яких скарг. Міокардит діагностують за збільшенням рівня креатинфросфокінази (КФК-МВ) у 2-4 рази відповідно до норми і порушенням ритму аускультативно та на ЕКГ (тахікардія, екстрасистолія). Для покращення діагностики "мінорних" форм міокардиту при ХЛ у ранню дисеміновану стадію хвороби показано проводити обстеження на КФК-МВ та ЕКГ усім хворим [1]. Іноді при ХЛ відмічають прояви перикардиту. Перебіг міоперикардиту при ХЛ, як правило, сприятливий, через декілька тижнів спостерігається видужання хворих. Ураження ендокарда, клапанів серця та фрормування вад серця при ХЛ зустрічається рідко. Клінічний аналіз доводить, що ураження серця при ХЛ не бувають ізольовані, завжди мають місце ушкодження інших органів (лімфраденопатія, ушкодження нервової системи, зовнішніх покривів, опорно-рухового апарату) [6].

Ураження суглобів при ХЛ може перебігати за артралгічним або артритичним типом із переважним залученням великих і середніх суглобів [8]. Артралгічна форма спостерігається у першій стадії захворювання. Найчастіше уражаються колінні, плечові, ліктьові, скронево-щелепні, суглоби кистей та стоп. Як правило, лайм-артрит характерний для 1-2 суглобів, однак у 1/3 пацієнтів спостерігаються мігруючі ураження до 10 суглобів [6].

Часто уражуються суглоби з боку укусу кліща - колінні (50\%), плечові (30 \%). Артритична фрорма перебігу супроводжується мігруючим болем у суглобах 3 випотом у синовіальну порожнину та рецидивами не менше, ніж 1 раз на 3 місяці [8]. Лайм-артрит диференціюють із ревматизмом і ревматоїдним артритом. Збудником ревматизму $\epsilon$ $\beta$-гемолітичний стрептокок групи А. Поліатрит при ревматизмі характеризується припухлістю та болючістю великих суглобів: колінних, гомілковоступневих, променевозап'ясткових, множинністю уражень, летючістю, різкою болючістю, збільшення об'єму суглоба, гладкою, гарячою на дотик шкірою над ураженим суглобом [18]. Суглобовий синдром при ревматоїдному артриті (РА) характеризується двостороннім симетричним залученням суглобів. Типове при РА залучення суглобів стоп і кистей, зап'ясть, колінних і ліктьових суглобів. Об'єктивні зміни - скупчення внутрішньосуглобового ексудату, набряк, різка болючість, рухові обмеження, локальна гіперемія і гіпертермія шкіри. РА притаманні ревматоїдні вузлики - підшкірно розташовані сполучнотканинні вузлики діаметром 0,5-2 см. Для них характерна округла фрорма, щільна консистенція, рухомість, безболісність, рідше - нерухомість унаслідок спаяності з апоневрозом. Ці утворення можуть носити одиничний або множинний характер, мати симетричну або несиметричну локалізацію в ділянці передпліч і потилиці [19].

Ураження нервової системи спостерігають у 10-25 \% пацієнтів із лайм-бореліозом [6]. Неврологічні прояви у хворих з'являються через декілька тижнів або місяців після укусу кліща. На ранній дисемінованій стадії проявляються менінгітом, черепно-мозковими невритами, руховими або чутливими радикулоневритами, лімфоцитарним менінгорадикулоневритом, множинними мононевритами, неяскраво вираженим енцефралітом [20]. У декількох достовірних випадках при ХЛ описані мієліт, хорея, церебральна атаксія, епілепсія. На пізній хронічній стадії ХЛ характерні хронічний енцесраломієліт, спастичний парез, атаксія, стерті розлади пам'яті, хронічна аксональна радикулопатія, рідко деменція [7]. У таблиці показано дисееренційну діагностику ХЛ із кліщовим енцефалітом.

За наявності менінгеального та енцефралітного синдромів проводять дисеренційну діагностику ХЛ з інфекційними (ентеровірусний, герпетичний, кліщовий, лімфоцитарний, коровий, туберкульозний) та інвазійними (амебний) менін- 
ISSN 1681-276Х. ВІСНИК НАУКОВИХ ДОСЛІДЖЕНЬ. 2018. № 1

Таблиця. Диференційна діагностика хвороби Лайма та кліщового енцефаліту

\begin{tabular}{|c|c|c|}
\hline Показник & Хвороба Лайма & Кліщовий енцефаліт \\
\hline Етіологія & $\begin{array}{l}\text { Бактерія Borrelia burgdorferi ряду Spirochaetales } \\
\text { родини Spirochaetaceae роду Borrelia }\end{array}$ & $\begin{array}{l}\text { Bipyc virus Tick-born encephalitis (VTBE) роду } \\
\text { Flavivirus родини Togaviridae екологічної групи } \\
\text { арбовірусів }\end{array}$ \\
\hline Епідеміологія & $\begin{array}{l}\text { Резервуари борелій - ссавці та птахи. Іксодові } \\
\text { кліщі - переносники та резервуари інфекції. Шляхи } \\
\text { зараження: трансмісивний, контактний (контамі- } \\
\text { нація випорожненнями кліща), аліментарний } \\
\text { (молочні продукти), трансплацентарний }\end{array}$ & $\begin{array}{l}\text { Основний резервуар вірусу - іксодові кліщі, додат- } \\
\text { кове джерело інфекції - дикі, свійські ссавці та } \\
\text { птахи. } \\
\text { Шляхи зараження - трансмісивний, аліментарний } \\
\text { (молочні продукти) }\end{array}$ \\
\hline Клініка & $\begin{array}{l}\text { Мігруюча еритема, регіонарна лімфаденопатія, } \\
\text { менінгеальний синдром, артрит, міокардит, } \\
\text { атріовентрикулярні блокади }\end{array}$ & $\begin{array}{l}\text { Гарячка, гіперемія обличчя, ін'єктовані склери та } \\
\text { кон'юктива, інтоксикація, менінгоенцефаліт, паре- } \\
\text { зи, паралічі, судоми, брадикардія }\end{array}$ \\
\hline Ускладнення & $\begin{array}{l}\text { Анкілози, фріброміалгії, синдром хронічної втоми, } \\
\text { енцефраломієліт }\end{array}$ & $\begin{array}{l}\text { Епілепсія, набряк мозку, крововиливи у мозок, } \\
\text { паралічі, інфекційно-токсичний міокардит }\end{array}$ \\
\hline Специфічна діагностика & $\begin{array}{l}\text { Мікроскопія біоптатів шкіри, крові, серологічні мето- } \\
\text { ди (ELISA, IФA), ПЛР }\end{array}$ & $\begin{array}{l}\text { Вірусологічне дослідження крові та } \\
\text { спинномозкової рідини, серологічні методи (РНГА, } \\
\text { ІФА, РЗК, РГГА), ПЛР }\end{array}$ \\
\hline Етіотропна терапія & $\begin{array}{l}\text { Антибіотики (пеніциліни, тетрацикліни, цефалоспо- } \\
\text { рини) }\end{array}$ & $\begin{array}{l}\text { Специфічний донорський імуноглобулін, } \\
\text { інтерферон, індуктори інтерферону (аміксин, лари- } \\
\text { фан, неовір), рибонуклеза (РНКаза) }\end{array}$ \\
\hline
\end{tabular}

гітами, порушенням мозкового кровообігу різної природи, розсіяним склерозом, синдромом Гієна-Барре [7].

ВИСНОВКИ Хвороба Лайма - це хронічне інфекційне трансмісивне зоонозне природно-осередкове захворювання, яке характеризується циклічним перебігом і мультисистемністю уражень. В Україні циркулюють 5 штамів борелій комплексу Bbsl. Диференційну діагностику лаймбореліозу проводять із бешихою, токсикодермією, еризи- пелоїдом, укусами членистоногих, ревматизмом, ревматоїдним артритом, інфекційними та інвазійними менінгітами, кліщовим енцефалітом, порушенням мозкового кровообігу різної природи, розсіяним склерозом, синдромом Гієна-Барре. Для покращення епідситуації щодо лайм-бореліозу в Україні потрібно проводити санітарнопросвітню роботу серед населення, акарицидні заходи та налагодити специфрічну діагностику даного захворювання.

\section{СПИСОК ЛІТЕРАТУРИ}

1. Сучасні епідеміологічні особливості лайм-бореліозу та критерії діагностики "мінорних" форм міокардиту / І. В. Будаєва, Г. О. Ревенко, Л. І. Кодола, С. О. Рясин // Семейная медицина. - 2016. - № 6(68). - С. 94-97.

2. Андрейчин М. А. Небезпечна динаміка інфекційної захворюваності в Україні / М. А. Андрейчин // Інсрекційні хвороби. 2017. - № 2(88). - С. 4-8.

3. Епідситуація із захворюваності на лайм-бореліоз в м. Тернопіль у 2016 р. / М. М. Павельєва, Б. Є. Козяр, І. І. Лесів [та ін.] // Довкілля і здоров'я : матеріали науково-практичної конореренції. - Тернопіль, 2017. - С. 120-121.

4. Медична мікробіологія, вірусологія та імунологія : підручник для студентів вищих медичних навчальних закладів. - 2-ге вид. I за ред. В. П. Широбокова. - Вінниця : Нова Книга, 2011. - 952 с.

5. Иноекционные болезни : учебник / О. А. Голубовская, М. А. Андрейчин, А. В. Шкурба [и др.] ; под ред. О. А. Голубовской. - К. : СВИ "Медицина", 2014. - 784 с.

6. Николов В. В. Болезнь Лайма / В. В. Николов // Клінічна імунологія. Алергологія. Інфектологія. - 2016. - № 4(93). - С. 47-54.

7. Возіанова Ж. І. Інфеецційні і паразитарні хвороби : у 3 т. I Ж. І. Возіанова. - К. : Здоров'я, 2002. - Т. 2. -658 с.

8. Попович О. О. Лайм-бореліоз: сучасна проблема інсректології / О. О. Попович // Актуальная инфеектология. - 2016. - № 3(12). - C. 114-122.

9. Хвороба Лайма: етіологія та епідеміологія / М. А. Крижановська, Т.В.Бігуняк, О. С. Редько, К. О. Бігуняк // Фундаментальные и прикладные исследования: проблемы и результаты / Badania podstawowe i stosowane: wyzwania i wyniki : Міжнародна науковопрактична конфреренція : збірник наукових доповідей. - Гданськ, 30.05.2017 - 31.05.2017. - С. 23-25.

10. Лайм-боррелиоз // Вестник инфектологии и паразитологии
[Электронный ресурс]. - Режим доступа: http://www.infectology. ru/nosology/infectious/bacteriosis/lyme.aspx

11. Симптомы болезни Лайма [Электронный ресурс]. - Режим доступа: http://okeydoc.ru/simptomy-bolezni-lajma/\#razdel5

12. Еризипелоїд [Електронний ресурс]. - Режим доступу: https://uk.wikipedia.org/wiki/\%D0\%95\%D1\%80\%D0\%B8\%D0\%B7 \%D0\%B8\%D0\%BF\%D0\%B5\%D0\%BB\%D0\%BE\%D1\%97\%D0\%B4

13. Бешиха свиней [Електронний ресурс]. - Режим доступу: http://svynarnyk.com/beshiha-svinej-simptomi-i-likuvannya-mozhnayisti-myaso-pislya-likuvannya-piki/

14. Медична паразитологія з ентомологією : навч. посіб. / В. М. Козько, В. В. М'ясоєдов, Г. О. Соломенник [та ін.] ; за ред. В. М. Козька, В. В. М'ясоєдова. - К. : ВСВ “Медицина”, 2015. - 336 с.

15. Укус паука, фрото: птицеед, каракурт, тарантул [Электронный ресурс]. - Режим доступа: http://parazityj.ru/ukusy/ukuspauka-foto-pticeed-karakurt-tarantul.html

16. Скорпионов укус [Электронный ресурс]. - Режим доступа: https://ukusinfo.ru/nasekomye/skorpiona-ukus.html

17. Маврутенков В. В. Лаймская болезнь. Общие вопросы (1 часть) / В. В. Маврутенков // Здоровье ребенка. - 2014. № 2(53). - C. 106-110.

18. Palindromic rheumatism or palindromic arthritis: causes, symptoms, treatment, prognosis [Electronic resource]. - Access mode: https://www.epainassist.com/joint-pain/palindromic-rheumatism-or-pre-rheumatoid-arthritis

19. Як лікувати ревматоїдний артрит [Електронний ресурс]. - Режим доступу: https://moyezdorovya.com.ua/yak-likuvatirevmatoyidnij-artrit/

20. Копча В. С. Труднощі діагностики нейробореліозу / В. С. Копча, І. С. Іщук, В. І. Кородюк // Інфекційні хвороби. -2016. - № 2(84). - C. 83-86. 


\section{CLINICAL POLYMORPHISM AND DIFFERENTIAL DIAGNOSIS OF LYME DISEASE}

Summary. Lyme borreliosis is a chronic natural focal transmissive infectious zoonotic disease, which is caused by Borrelia burgdorferi sensu lato (Bbsl). The West of Ukraine, including Ternopil region, is the endemic area of Lyme disease. The study presents a review of the literature analysing the polymorphic character of Lyme borreliosis clinical manifestations, provides data about the differential diagnosis of Lyme dermatitis, Lyme arthritis, and neuroborreliosis.

The aim of the study - to learn Lyme borreliosis with the aim of improving the disease diagnosis and prevention among the population of Ukraine.

Materials and Methods. A questionnaire was answered by 326 people aged between 5 and 80 . Statistical methods were used to establish the seasonality and localisation of tick bites in the survey participants, the number of patients, whose blood samples were examined for borrelia infection and who received preventive treatment. The patient complaints were analysed.

Results and Discussion. In Ukraine 5 strains of borellial complex Bbsl: Bbss, B.afzelii, B.garinii, B.valasiana, A14S circulate. The aforementioned borrelia genospecies are associated with the prevalence of corresponding clinical forms of Lyme borreliosis: arthritis is linked to Bbss, neurological manifestations are linked to B.garinii, skin manifestations to B.afzelii. Bbs/ is the cause of etiologically undiagnosed $16.7 \%$ neurological and $20.7 \%$ pseudorheumatological pathologies. 326 survey participants aged between 5 and 80 included 229 tick-bitten individuals. The disease has a seasonal character which is connected to the tick activity periods. $59.2 \%$ tick bites happened to the survey participants in summer, $25.7 \%$ in spring, $15.1 \%$ in autumn. 20 patients (8.73 \% of the tick-bitten individuals) underwent laboratory blood tests for borrelia, the test result was positive in 6 cases. The most frequent complaints were erythema migrans (10 patients) and joint swelling (6 patients).

Conclusions. Lyme borreliosis is a chronic infectious transmissive zoonotic natural focal disease, which is characterized by cyclic course and multisystemic damages. In Ukraine five strains of borelia complex Bbsl are common. Differential diagnosis of Lyme borreliosis is developed with erysipelas, toxicodermia, erysipeloid, anthropod bites, reumatism, rheumatoid arthritis, infectious and invasive meningitis, tick-borne encephalitis, brain blood circulation disorders of different aetiology, multiple sclerosis, Guillain-Barré syndrome.

Key words: Lyme borreliosis; Lyme disease; Borrelia burgdorferi sensu lato; erythema migrans; myocarditis; nervous system damage.

(СТ. В. Бигуняк, Е. О. Бигуняк, О. С. Редько

ГВУз “Тернопольский государственный медицинский университет имени И. Я. Горбачевского” КЛИНИЧЕСКИЙ ПОЛИМОРФИЗМ И ДИФФЕРЕНЦИАЛЬНАЯ ДИАГНОСТИКА БОЛЕЗНИ ЛАЙМА

Резюме. Лайм-боррелиоз - это хроническое природно-очаговое трансмиссивное инфекционное зоонозное заболевание, вызываемое боррелиями Borrelia burgdorferi sensu lato (Bbsl). Западный регион Украины, в том числе Тернопольская область, является эндемическим очагом болезни Лайма. В статье представлен обзор литературы, посвященный анализу полиморфризма клинических проявлений лайм-боррелиоза, приведены данные по диффреренциальной диагностики лайм-дерматита, лайм-артрита и нейроборелиоза.

Цель исследования - изучить заболевания лайм-боррелиозом для улучшения диагностики и просилактики его среди населения Украины.

Материалы и методы. Проведено анкетирование 326 человек в возрасте от 5 до 80 лет. С помошью статистического метода определены сезонность и места укусов опрошенных людей клещами, количество лиц, которым проводили лабораторные исследования крови по выявлению боррелий и профилактическое лечение, проанализированы жалобы больных.

Результаты исследований и их обсуждение. В Украине циркулируют 5 штаммов боррелий комплекса Bbsl: Bbss, B.afzelii, B.garinii, B.valasiana, A14S. Эти геновиды боррелий ассоциируются с преобладанием соответствующих клинических фрорм лайм-боррелиоза: артриты - c Bbss, неврологическая манифестация - с B. garinii, кожные проявления - c B. afzelii. Bbsl является причиной этиологически недиагностированных (16,7 \%) неврологических и (20,7 \%) псевдоревматологических патологий. Среди анкетируемых нами 326 людей в возрасте от 5 до 80 лет было 229 укушенных клещами. Характерна сезонность заболевания, которая связана с периодами активности клещей. 59,2 \% укусов клещами среди опрошенных людей случились летом, 25,7 \% - весной, 15,1 \% - осенью. Лабораторные исследования крови среди укушенных на предмет выявления боррелий проводили 20 (8,73 \%) пациентам, у 6 был положительный результат. Чаще всего больные жаловались на появление мигрирующей эритемы (10 человек) и отеков суставов (6 человек).

Выводы. Болезнь Лайма - это хроническое инфекционное трансмиссивное зоонозное природно-очаговое заболевание, характеризующееся циклическим течением и мультисистемностью поражений. В Украине циркулируют 5 штаммов боррелий комплекса Bbsl. Дифрференциальную диагностику заболевания лайм-боррелиозом проводят с рожей, токсикодермией, эризипелоидом, укусами членистоногих, ревматизмом, ревматоидным артритом, иноекционными и инвазионными менингитами, клещевым энцефалитом, нарушением мозгового кровообращения различной природы, рассеянным склерозом, синдромом Гийена-Барре.

Ключевые слова: болезнь Лайма; лайм-боррелиоз; Borrelia burgdorferi sensu lato; мигрирующая еритема; міокардит; поражения нервной системы. 